\title{
Psychometric properties of persian version of Fear of Self Questionnaire related Obsessive Compulsive Disorder
}

\author{
Nezamaddin Ghasemi $^{1}$, Marzieh Sadeghzadeh ${ }^{1}$, Maryam Azarniushan ${ }^{2}$ \\ 1-Assistant Professor, Department of Psychology, Salman Farsi University of Kazerun, Kazerun, Iran. \\ 2- MSc, Department of Clinical Psychology, Shiraz University, Shiraz, Iran. \\ Corresponding Author: Nezamaddin Ghasemi $\quad$ E-mail: Dr.ghasemi@kazerunsfu.ac.ir
}

Received: 13/09/2021 Accepted: 21/12/2021

\begin{abstract}
Introduction: The cognitive aspect of obsession involves the evaluation of oneself, which is often accompanied by a fear of what one is -or can be.

Aim: The aim of this study was to investigate the psychometric properties of the Fear of Self Questionnaire, which measures the level of this fear in the context of obsessive-compulsive disorder.

Method: The present study was a descriptive study and its statistical population included all students of Shiraz University in the academic year 2020-2021. The sample of the present study also included 360 students who were participated in this research by answering the online link of questions. In addition to the Persian version of the Fear of Self Questionnaire, other research tools were included the Obsessive Beliefs Questionnaire (OBQ-42), the Maudsley Obsessional Compulsive inventory (MOCI), the Self-Ambivalence Measure (SAM), and the Depression, Anxiety, and Stress Scale (DASS-21). Data analysis was conducted by confirmatory factor analysis, convergent validity, Cronbach's alpha coefficient, and test-retest reliability coefficient in SPSS-24 and AMOS-22 software.
\end{abstract}

Results: The results of factor analysis confirmed the one-factor structure in the Persian version of the Fear of Self Questionnaire. Cronbach's alpha and test-retest coefficients were 0.94 and 0.86, respectively, that shows the internal consistency and optimal reliability of this questionnaire. In addition, the correlation between the scores of the Persian version of the questionnaire and other research tools ranged from 0.49 to 0.81 , which has confirmed its convergent validity.

Conclusion: Considering the psychometric properties of the Persian version of the Fear of Self Questionnaire, its usage can be recommended in research related to the symptoms and various dimensions of obsession.

Keywords: Obsessive- Compulsive Disorder, Psychometrics, Fear of self

How to cite this article: Ghasemi N, Sadeghzadeh M, Azarniushan M. Psychometric properties of persian version of Fear of Self Questionnaire related Obsessive Compulsive Disorder. Shenakht Journal of Psychology and Psychiatry. 2022; 8 (6): 24-36 .URL: http://shenakht.muk.ac.ir/article-1-1234-en.pdf

Copyright () 2018 the Author (s). Published by Kurdistan University of Medical Sciences. This is an open access article distributed under the terms of the Creative Commons Attribution-Non Commercial License 4.0 (CCBY-NC), where it is permissible to download, share, remix, transform, and buildup the work provided it is properly cited. The work cannot be used commercially without permission from the journal. 


\title{
ويثگىهاى روانسنجى نسخه فارسى برسشنامه ترس از خود مرتبط با وسواس فكرى عملى
}

\author{
نظام الدين قاسمى'، مرضيه صادق زاده ‘ مريم آذرنيوشان \\ ا. ا.استاديار، گرووه روانشناسى، دانشخاه سلمان فارسى، كازرون، ايران.

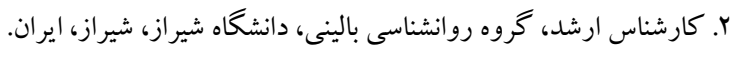

ايميل:Dr.ghasemi@kazerunsfu.ac.ir

مولف مسئول: نظام الدين قاسمى كارى

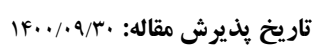

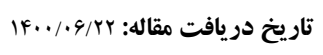

جكيده

مقدمه: جنبه شناختى وسواس ارزيابى فرد از خود را در برمى گيرد كه اغلب با ترس وى از آنجه هست -يا مىتواند باشد- همراه مى گردد.

هدف: يزوهش حاضر با هدف بررسى ويزگ هاى روانسنجى يرسشنامه ترس از خود كه به اندازهيرى اين ترس در بافت علائم وسو اس مى يردازد، انجام شد.

روش: يزوهش از نوع توصيفى همبستگى بود. جامعه آمارى كليه دانشجويان دانشكاه شيراز بودند كه به روش نمونه گيرى در دسترس

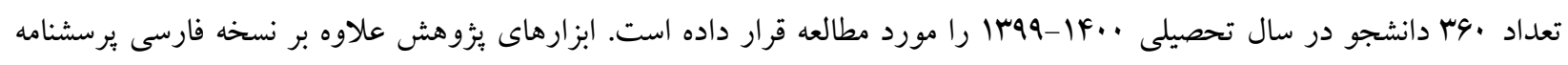

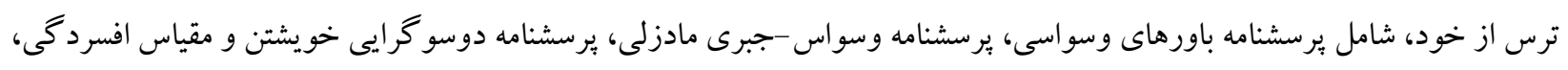

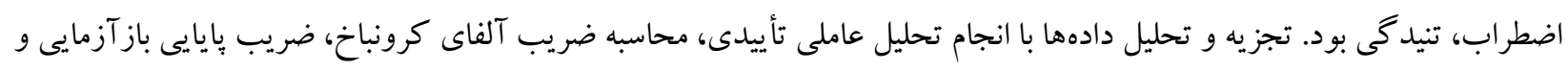

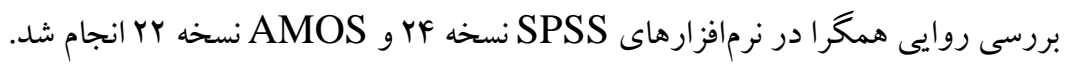

يافتهها: نتايج تحليل عاملى مؤيد ساختار تكك عاملى در نسخهُ فارسى يرسشنامه ترس از خود بود. ضرايب آلفاى كرونباخ و باز آزمايى

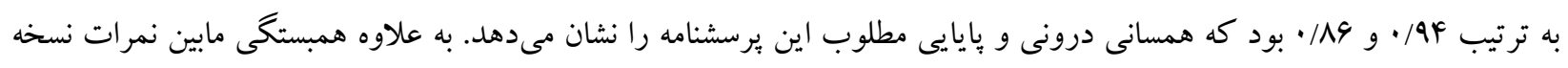

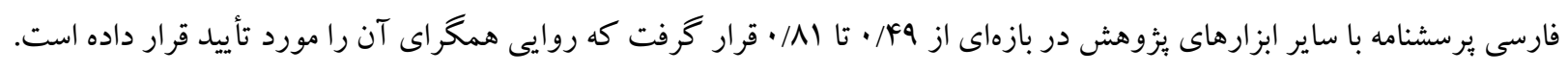
نتيجه كيرى: با توجه به ويزگ هاى روانسنجى نسخه فارسى يرسشنامه ترس از خود، مىتوان كاربرد آن را در يزوهش هاى مرتبط با علائم و ابعاد مختلف وسواس توصيه نمود. كليدوازهها: وسواس فكرى - عملى، روانسنجى، ترس از خود 
در سالهاى اخير بثوهشخرانى از قبيل آردما، مولينگك،

مقلدمه

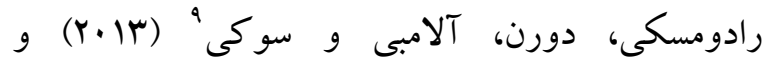
از دهه ،191 دو مدل نقص در عملكرد عصب كلار كى" (10 (Y. با تأكيد بر مفهوم دركك خود، معتقدند ارزيابى افكار نافذ در راستاى تهديد ادراك خويشتن و برحسب اينكه فرد در جه حوزههايى از زندگى به خود اعتماد ندارد، مىتواند به رفتارهاى اجبارى براى خنثى كردن اين افكار منجر شود. به همين خاطر مدلهاى شناختى اخير وسواس معتقدند از آنجايى كه محتواى اغلب وسواس ها در افراد موضوعات مختلفى را دنبال مى كند ممكن است محتواى وسواس افراد توسط ابعاد خود تعيين شوند (آردما، ونگك، آيوت، نيلى و بارابى"'،

كلاركs (Q (Y) در مدل شناختى به نقش بالقوه ابعاد خود آسيب يذير، به صورت افكار نافذى كه فرد آن را ناهمخوان با خود ادراكك مى كند و از ديد كاه فرد قابل توجه و تهديدآميز تفسير مىشوند، به عنوان مكانيسم علّى همزمان در ايجاد و تداوم وسواس اشاره دارد. دورون،

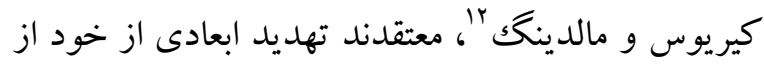
قبيل بذيرش اجتماعى، شايستكى شغلى، اخلاق و روابط كه براى فرد ارزشمند است و فرد در آن اعتماد به خود ندارد مى تواند به هدف ارزيابى، مشغله ذهنى و اضطراب تبديل شود؛ زيرا محتواى اغلب وسواسها افكار خود ارجاعى و ارزيابى نادرست از خود هستند (آكويلار،

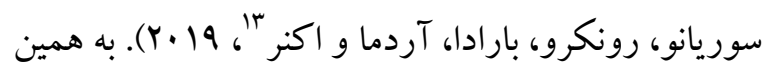

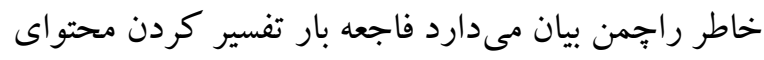
افكار كه اغلب آشكاركننده جنبههاى وينهان، منفى و و

9 - Aardema, Moulding, Radomsky, Doron, Allamby \& Souki

${ }^{10}$ - Clark

${ }^{11}$ - Aardema, Wong, Audet, Melli, Baraby

${ }^{12}$ - Doron, Kyrios \& Moulding

${ }^{13}$ - Aguilar, Soriano, Roncero, Barrada, Armada \& Ocner

\footnotetext{
1- Gruner \& Pittenger

2- Hezel \& McNally

3 - Kim, Lee, Cha, Kim, Chang \& Lee

4- Salkovskis

5 - Salkovskis \& Kobori

${ }^{6}$ - Rachman

7. Wong, Lim, Black \& Grisham

${ }^{8}$ - Cervin, Perrin, Olsson, Claesdotter-Knutsson \& Lindvall
} 
قرار دهد، وجود ندارد. ابزارهايى از قبيل وضوح خود

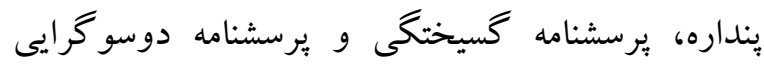
خود، اغلب داراى محدوديتهاى از قبيل طبقهبندى خود براساس توصيفات افراطى خود، اندازهيرى ابعاد متعارض خود، تأكيد بيش از اندازه بر اندازهگيرى ميزان وضوح باورهاى مربوط به خود و عدم استقلال اين برسشنامهها از عزت نفس و بـى تصميمى مىباشند

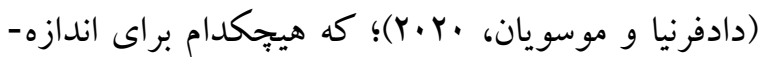
كيرى ترس از خود كه مستقل از تفسير افكار سرزده باشد، طراحى نشدهاند. يرسشنامه ترس از خود، در اين راستا و در ارتباط با مقياس دوسو گرايى خود، اما مستقل

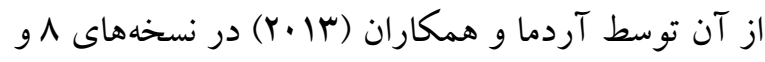

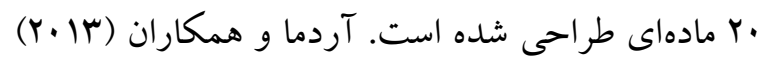
معتقدند ترس از خود نمىتواند بهخودىخود بيانگر

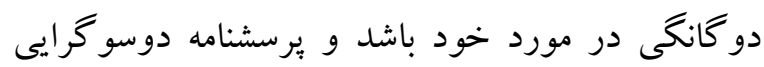
خود تنها ابعاد ارزشمندى خود را مىسنجد؛ بنابر اين بايد ابزارى طراحى شود كه بتواند ترس از خود را مستقيم هدف قرار داده و آن را مستقل از تفسير افكار نافذ اندازهـ كيرى كند. يرسشنامه ترس از خود بر همين اساس در

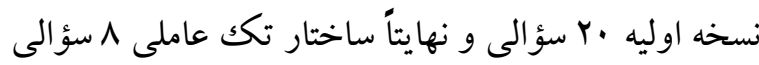
در ارتباط با وسواس منتشرشده است. با توجه به اهميت سازه ترس از خود در سببشناسى و درمان وسواس و ازآنجايى كه بررسى سازه ترس از خود، در علتشناسى وسواس نياز به يزوهشهاى بيشترى دارد. انتظار مىرود با گسترش ابزارهاى اندازهيرى ترس از

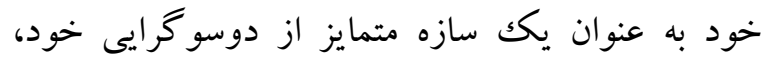
مطالعات حوزه وسواس توسعه يابد. بر اين اساس هدف بثزوهش حاضر بررسى ويز گیىهاى روانسنجى نسخه فارسى برسشنامه ترس از خود در جامعه ايرانى بود.
ترسناكك خود است، به طور مستقيم با ترس از خود ارتباط دارد (ونگگ، ليم، بلك و گريشام، الr.r). كويدانو و ليوتى ' (س/91) به نقل از دادفرنيا و موسويان (Y.Y.) دوسو گرايى خود به شكل تجربه عدم قطعيت، تعارض و اشتغال ذهنى با خود را در شكل گيرى وسواس مطرح مى كنند و معتقدند اين افراد اغلب در مورد ارزش خود

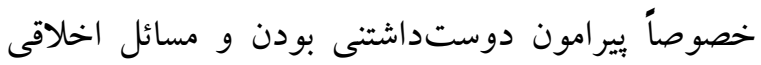
دجار ترديد هستند. در الكوى دوسو گرايى وابستگى طرد اعتقاد بر اين است كه برخوردارى از اين الكوى شناختى با ايجاد ترديد در احساس ارزش خود، باعث مىشود افراد مزاحمتهاى ناهمخوان با خود كه ارزش فرد را به جالش مى كشند را به احتمال زياد از طريق وسواس عملى پِاسخ دهند و با خنثى كردن اين تهديدها ارزش خود را بازيابند. از سويى ديخر آرادما و همكاران (Y.M) استدلال مى كنند ترس از خود متمايز از دوسو گرايى نسبت به خود- به عنوان يك عامل آسيبيذير در وسواس خصوصاً در حوزه مذهبى، جنسى و يرخاشخرى - با ايجاد سردر گمى استباطى باعث مىشود فرد مبتلا به وسواس، احتمال وقوع فكر را با قصد و انكيزه ارتكاب فكر اشتباه بحيرد و از هر روايت وسواسى شكل كرفته در ذهن بترسد؛ و با ارزيابى نادرست و ترس از اينكه خود به جهه جيزى ممكن است تبديل شود (مثلاً من ممكن است فرزندم را بكشم) تحت سيطره افكار نافذ وسواسى قرار بـيرد. عليرغم اهميت شناخته شده مفهوم ترس از خود در ايجاد

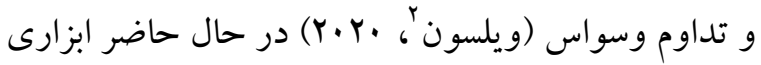

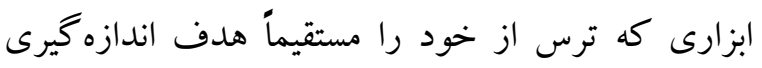

\footnotetext{
1. Guidano \& Liotti

2- Wilson
} 
اين مدت . • دانشجوى دانشگاه شيراز برسشنامههاى موجود در آن را تكميل نمودند. تمامى اين دانشجويان جهت انجام كام جهارم و دستيابى به نسخه نهايى يرسشنامه ترس از خود، به عنوان نمونه بيزوهشى در نظر

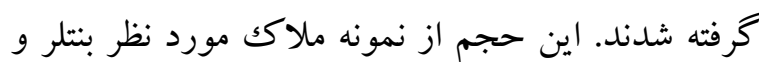

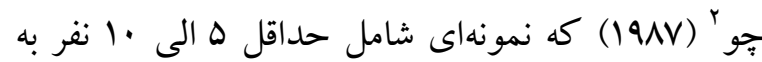
ازاى هر كويه را براى انجام تحليل عاملى تأييدى مناسب

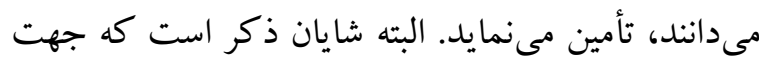
بررسى بايايى باز آزمايى برسشنامه ترس از خود نيز نمونه مجزايى شامل •ب دانشجوى مقطع كارشناسى (Yr د دختر و

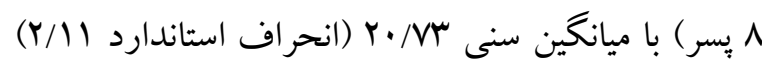
در دو نوبت اجرا به فاصله زمانى ·ا روز به سؤالات موجود در لينك ئزوهش بِاسخ دادند. تجزيهوتحليل دادهها با انجام تحليل عاملى تأييدى، محاسبه ضريب

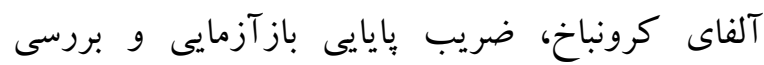
روايىهمخرا در نرمافزارهاى SPSS نسخه SF AMOS

ابزار مقياس افسردكى، اضطراب، تنيدكى"! اين مقياس، نسخه

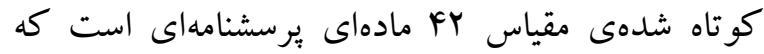
توسط لويبند و لويبند درر سال 1990 تدوين گرديده كه مهاه شامل I M ماده است. اين مقياس داراى ب زير مقياس افسردگى، اضطراب و تنيدگى است كه هر يك V ماده را به خود اختصاص مىدهند. نمره گذارى اين مقياس براساس طيف ليكرت جهار درجهاى از صفر (اصلاً) تا سه (زياد) است كه حداقل و حداكثر امتياز قابل كسب در

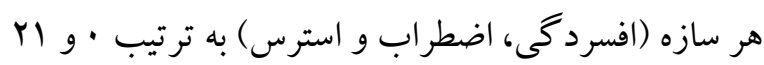

2- Bentler \& Chou

3 - Depression, Anxiety \& Stress Scale (DASS)

4- Lovibond \& Lovibond
يثزوهش حاضر از نوع توصيفى همبستكى بود. جامعه

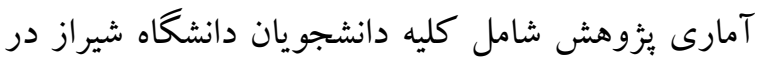

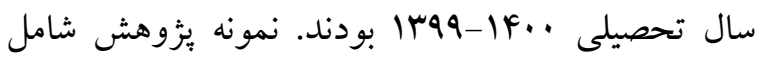

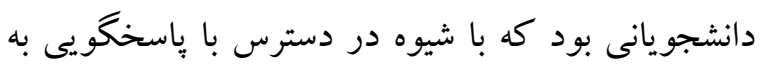
لينك سؤالات در اين يزوهش مشاركت نمودند. در اين

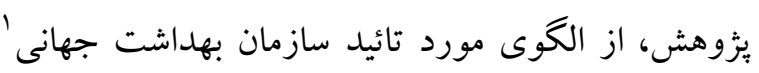
(Y..4) انطباق ابزارهاى اندازه گيرى لازم مىداند. بر همين اساس در كام نخست، نسخه اصلى برسشنامه ترس از خود توسط دو متخصص روانشناسى به فارسى ترجمه گرديد؛ در كام دوم، نسخه اوليه فارسى توسط يك مترجم مسلط به زبان مبدأ و مقصد، مجدداً به زبان انگليسى باز گردانده لئه شد و سبس توسط يكى از متخصصين آموزش زبان انگليسى با نسخه اصلى ابزار مقايسه گُرديد. در مرحله سوم به منظور بررسى روشنى و دقت عبارات ترجمه شده، هر دو نسخه فارسى و انگليسى مورد بازبينى و اصلاح دو نفر از اساتيد روانشناسى دانشگاه قرار گرفت. به علاوه در 1. اين مرحله، نسخه فارسى وبرسشنامه در اختيار دانشجوى كارشناسى (^ بـر و Y دختر) قرار كرفت تا نسبت به روشنى و مفهوم بودن جملات اطمينان حاصل كردد. جهت انجام مرحله جهارم و دستيابى به نسخه فارسى نهايى، ترجمه به دست آمده از برسشنامه ترس از خود به همراه ساير ابزارهايى كه در ادامه معرفى شده است، به صورت يكك فرم الكترونيك در آمده و در قالب يكك لينك در گروههاى مجازى دانشجويان دانشگاه

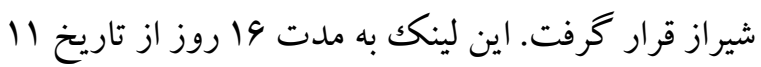

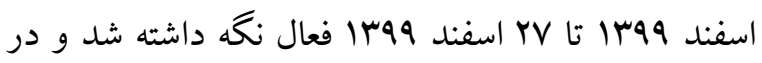

\footnotetext{
1- World Health Organization
} 


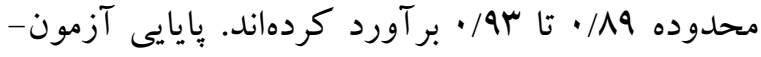
بازآزمون حاصل از بررسى ويز گیىهاى روانسنجى اين يرسشنامه در ايران براى اولين بار توسط شمس، قديرى و

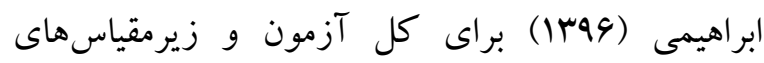
مسئوليت بذيرى نسبت به تهديد و خطر، كمالطبى و نياز به كسب اطمينان و اهميت و كنترل افكار به ترتيب معادل

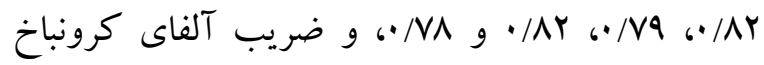

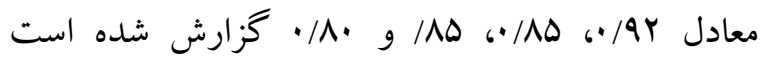

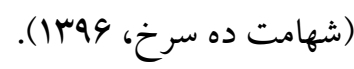

يرسشنامه وسواسى- جبرى مادزلى ؛ اين :برسشنامه

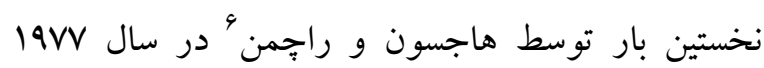

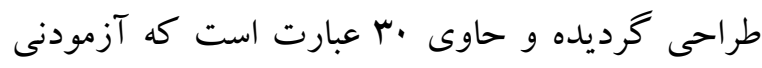
بايستى در مورد هر يك از آنها گزينهى درست و و نادرست را انتخاب كند. نمرهى بالاتر در اين مقياس نشانگر علائم وسواسى-جبرى بيشتر است. اين برسشنامه براى اندازهيرى شدت علائم وسواس فكرى-عملى

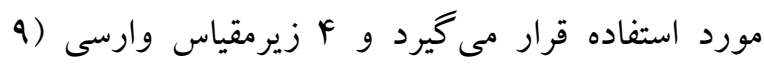
كزينه)، شست و شو (l شك و ترديد (V ₹زينه) را دارا است. هاجسون و راجمن

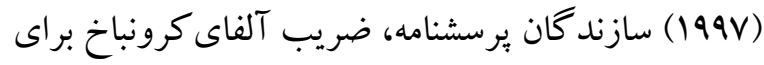
هر يكك از اين زيرمقياسها را به ترتيب V/ •، A/•، V/ • و V/ • ₹زارش كردهاند. در بررسىهاى انجام گرفته توسط

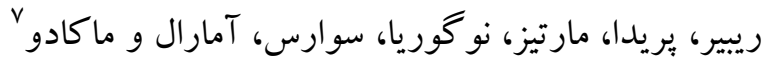
(Y.IV) نزديكك •^/ • براى تمامى زيرمقياسها بدست آمده است. بررسى קيايايى كل اين آزمون در ايران توسط دادفرنيا در

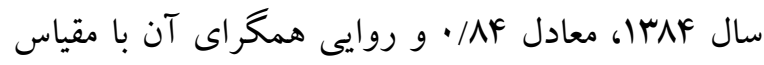

5 - Maudsley Obsessional Compulsive inventory (MOCI)

${ }^{6}$ - Hodgson \& Rachman

7- Ribeiro, Pereira, Martins, Nogueira, Soares, Amaral \& Macedo
است (لوويبند و لوويبند، 199ه). زانون، برنز، بإيتيستا،

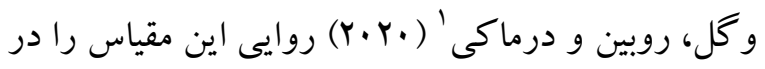
ميان ^ كشور برزيل، كانادا، هنگ كنگ كُ، رومانى، تايوان، تركيه، امارات متحدهى عربى و ايالاتمتحدهى آمريكا بررسى و مورد تائيد قرار دادند. در ايران نيز اعظمى،

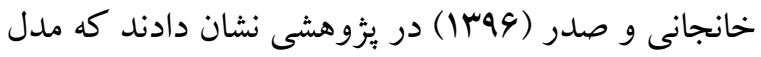
r عاملى (افسردگى - اضطراب-استرس) براى كل دانشجويان توسط تحليل عاملى تأييدى مورد تائيد قرار

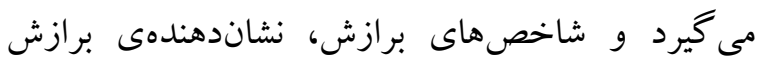
خوب دادهها با مدل ب عاملى است. يُوهش آنان نشان داد همبستكى منفى اين مقياس با فرم كوتاه مقياس بهزيستى روانشناختى ريف، نيز تائيد كننده روايى اين

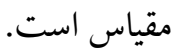
يرسشنامه باورهاى وسواسى"! اين :برسشنامه يك مقياس خود كزارشى است كه داراى بF سؤ ال بوده و فرم كو تاه شدهى برسشنامهى سؤ الى اصلى است كه نخستين بار توسط كارگروه شناختهاى وسواسى جبرى " تدوين شده است. اين يرسشنامه ابعاد بيمارىزايى در حوزهى شناختى را در بيماران وسواسى جبرى مورد بررسى قرار مى دهد. ياسخ ها شامل نشان دادن مخالفت و مو افقت با هر

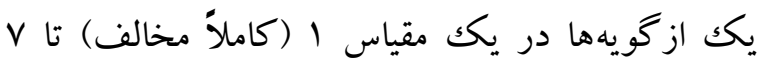
(كاملاً موافق) است. آزمون از ب زيرمقياس احساس مسئوليت براى صدمه و آسيب، كمالطلبى و نياز به برخوردارى از اطمينان، اهميت دادن به افكار و كنترل افكار تشكيل شده است. گنگگ، كر ك، هرناندز-والانت،

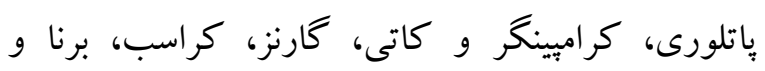

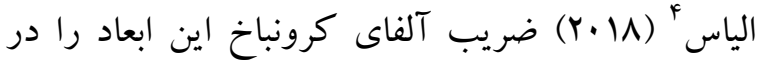

\footnotetext{
1- Aardema, Moulding, Radomsky, Doron, Allamby \& Souki

${ }^{2}$ - Obsessive Beliefs Questionnaire (OBQ)

3 - Obsessive Compulsive Cognitions Working Group (OCCWG)

4- Gagne, Van Kirk, Hernandez-Vallant, Potluri, Krompinger, Cattie, Garner, Crosb, Brenna \& Elias
} 
براى كل يرسشنامه معادل /91/ است و اين جهار ابعاد به طور كلى قادر به توضيح / 1 درصد واريانس بودند.

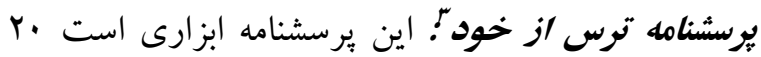

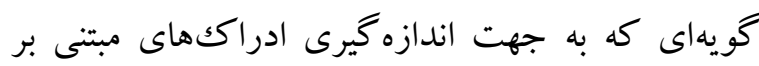
ترس از خويشتن توسط آرادما و همكاران (سا.ب) تدوين كرديد. نمره گذارى اين يرسشنامه در مقياسى از الو (كاملاً مخالف) تا 9 (كاملاً موافق) است. سازند كان برسشنامه بره فرم ^ سؤالى تكك عاملى آن را در جامعه غير بالينى و در ارتباط با ابعاد وسواس مورد تائيد قرار دادهاند. تحليل عاملى آن در كانادا، استراليا و ايتاليا همسانى درونى (آلفاى كرونباخ=

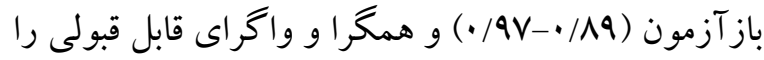
نشان داده است (آرادما، مولينگك، رادومسكى، دورن،

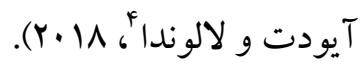

يافتهها

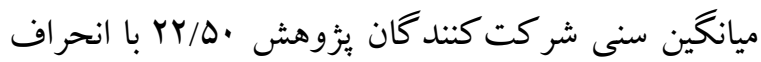

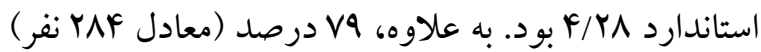
را دانشجويان دختر و اY درصد (معادلV9 نفر) را دانشجويان پير تشكيل دادهاند. همجينين VA درصد آزمودنىها در مقطع تحصيلى كارشناسى، 19 درصد در مقطع كارشناسى ارشد و ب درصد در مقطع دكترى به تحصيل اشتغال داشتند. تنها م درصد دانشجويان شركت كننده اعلام نمودند كه تا يِيش از اين يزوهش جهت موضوعى با عنوان وسواس به مشاور مراجعه كرده و 9V درصد تا زمان انجام اين مطالعه هيج مراجعهاى جهت دريافت كمك حرفهاى در موضوع وسواس

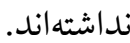

${ }^{3}$ - Fear of Self Questionnaire (FSQ)

4- Aardema, Moulding, Melli, Radomsky, Doron, Audet \& Lalonde
وسو اسى جبرى ييل براون معادل AV/ • بر آورده شده است

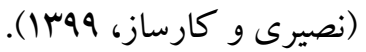

يرسشنامه دوسوكرايع خود ؛ اين هرسشنامه يك ابزار خود گزارشى است كه نخستين بار توسط بار و كيريوس در سال V P. P و براساس مفهوم دوسو گرايى نسبت به خود گويدانو و ليوتى براى سنجش تجربه عدم قطعيت، تعارض و اشتغال ذهنى به خود طراحى شده و شامل 19 كويه با طيف ليكرت اصلاً (نمره •) تا كاملاً موافق (نمره F) است. نمرات حاصل از اين برسشنامه بين · تا V9 قرار خو اهد گرفت و كسب نمرات بالاتر به معناى شدت بيشتر

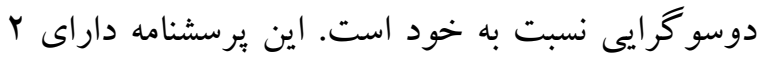
عامل دوسو گرايى نسبت به ارزش خود (سا گويه) و دوسو گرايى نسبت به اخلاق (4 گويه) است. بار و و

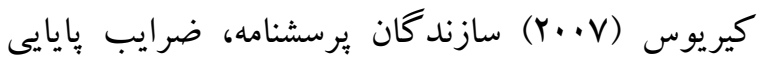
بازآزمايى مطلوب و ضرايب آلفاى كرونباخ براى هر يكك از عو امل اين مقياس و در هر دو نمونهى بالينى و غير

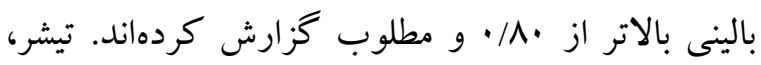

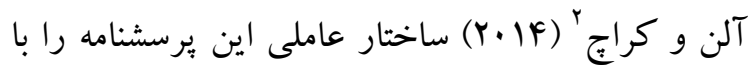
روش تحليل عامل اكتشافى در نمونه غير بالينى بررسى و "r عامل دوسو گرايى در مورد، ارزش خود، دوسو گرايى اخلاقى و خودآكاهى جمعى را شناسايى كردند. اين يرسشنامه در ايران و در جامعهى دانشجويان توسط دادفرنيا و موسويان (99 I) مورد بررسى روانسنجى قرار كرفته است كه در بيى آن F عامل افكار متعارض در مورد خود، ديد گاه دوقطبى نسبت به خود، نخرانى راجع به قضاوت ديكران و اشتغال ذهنى در مورد ارزش خود بدست آمد و مشخص كرديد كه ضريب آلفاى كرونباخ
${ }^{1}$ - Self-Ambivalence Measure (SAM)

${ }^{2}$ - Tisher, Allen \& Crouch 
استفاده شد. هرجند يِش از آن، به منظور اطمينان از كفايت نمونه گيرى و قابليت عاملى شدن دادهها به شاخص كيسر-مير -اكلين و آزمون بارتلت رجوع شد.

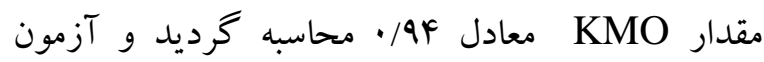
بارتلت با مقدار ...19 و درجهُ آزادى .19 در سطح

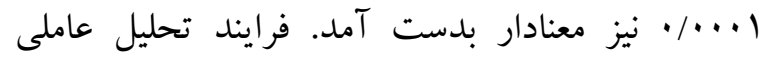
تأييدى نشان داد كه نسخه فارسى برسشنامه ترس از خود

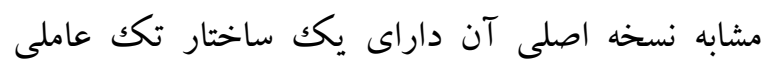
است. شاخص هاى برازش مربوط به اين تحليل عاملى در جدول ارائه شده است.
براى بررسى روايى نسخه فارسى برسشنامه ترس از خود، نخست از نسبت روايى محتوايى لاوشه استفاده شد. از آنجا كه در محاسبه اين نسبت، اظهارنظر ^ متخصص روانشناسى مورد توجه قرار گرفت؛ لذا مقدار بحرانى براى نسبت روايى محتو ايى معادل هV/ • در نظر كرفته شد

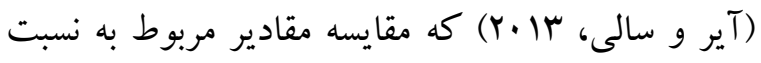

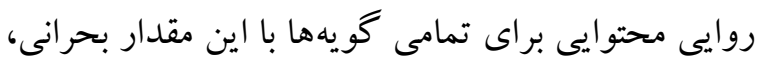
از روايى محتوايى نسخه فارسى برسشنامه ترس از خود دلالت مى كند. جهت بررسى ساختار عاملى بِرسشنامه از تحليل عاملى تأييدى در نرمافزار

جدول ا شاخصهاى برازش مرتبط با تحليل عاملى تأييدى

\begin{tabular}{|c|c|c|c|c|c|c|c|}
\hline RMSEA & AGFI & GFI & NFI & IFI & CFI & CMIN/DF & شاخص \\
\hline .1 .4 &.$/ 90$ &.$/ 99$ &.$/ 90$ &.$/ 99$ &.$/ 94$ & $r / \& q$ & مقدار \\
\hline$<\cdot / \cdot v$ & $\geq \cdot / 40$ & $\geq \cdot / 90$ & $\geq \cdot / 90$ & $\geq \cdot / 90$ & $\geq \cdot / 9 \Delta$ & $<r$ & مقدار قابل قبول \\
\hline
\end{tabular}

آزادى و ريشه خطاى ميانگين مجذورات تقريب به ترتيب • س/r و 9. قرار مى گيرند. بار عاملى مربوط به گويههاى نسخه

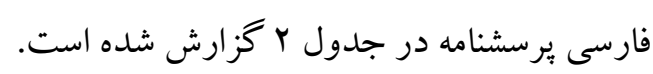

جنانكه در جدول ا مشاهده مى گردد مقادير شاخصهاى نيكويى برازش، برازش تطبيقى، برازش افزايشى و برازش

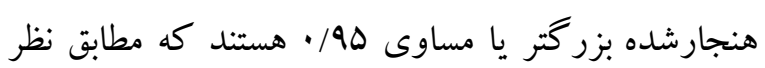

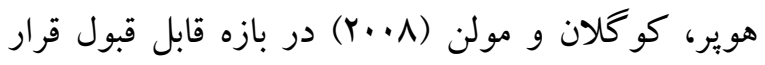
مى گيرند. مقادير دو شاخص نسبت مجذور خدى بر درجه

\begin{tabular}{|c|c|c|}
\hline با نمره كمبتكى & بارعاملى & كويه \\
\hline$\cdot 194$ & $\cdot 19$ & 1- اغلب اوقات شخصيت خودم رازير سؤال مىبرم. \\
\hline$\cdot 191$ & $\cdot / \Delta \Delta$ & r- براى اطمينان از درستى فكر و رفتارم، بايد دائماً حواسم به خودم و كارهايم باشد. \\
\hline$\cdot / 94$ & $\cdot / \Delta \mathrm{V}$ & ץ- نكران اين هستم كه افكار درونى من ممكن است نشاندهنده جه جيزهايى در شخصيتم باشد. \\
\hline$\cdot 19 \mathrm{~V}$ & $\cdot 190$ & F- از اين مى ترسم كه نكند آدم خشن يا ديو انهاى باشم. \\
\hline$\cdot / \mathrm{rr}$ & $\cdot / \mathrm{rr}$ & ه- بدون ترديد خودم را جزء آدمهايى مى دانم كه بايد هميشه احساس كناه كنند. \\
\hline$\cdot 199$ & $\cdot 190$ & 4- اغلب اوقات خصو صيات اخلاقى خودم را زير سؤال مىبرم. \\
\hline$\cdot / \mathrm{Nr}$ & $\cdot 191$ & V- اغلب اوقات سلامتى عقل خودم رازير سؤ ال مىبرم. \\
\hline$\cdot 190$ & $\cdot 194$ & ^- اكر ديخر ان واقعيت مرا مى دانستند، حتماً از من مىترسيدند. \\
\hline
\end{tabular}




\begin{tabular}{|c|c|c|}
\hline$\cdot / \mathrm{VI}$ & $\cdot 199$ & 9- اغلب نيت يا خواستههاى خودم رازير سؤال مىبرم. \\
\hline$\cdot / V^{F}$ & $\cdot / \mathrm{W}$ & • خودم يیدا كنى از اينكه به درون خود توجه كنم، مىترسم. جون از جيزى كه ممكن است در مورد \\
\hline$\cdot / N r$ & $\cdot / \mathrm{Nr}$ & |1- احساس مى كنم در درون من، بخش بدذاتى وجود دارد كه مى خواهد خود را نشان دهد. \\
\hline$\cdot / \Delta \wedge$ & $\cdot / \Delta \cdot$ & r ا - مى ترسم به آدمى تبديل شوم كه مى تواند دست به كارهاى غير اخلاقى بزند. \\
\hline$\cdot / \mathrm{Mr}$ & $\cdot / \mathrm{V}$ & سا - اغلب نخر ان اين هستم كه افكار بدى در سر داشته باشم. \\
\hline$\cdot / N$ & $\cdot / \mathrm{Nr}$ & fl | از آن آدمى كه مىتوانم باشم، مىترسم. \\
\hline$\cdot / \mathrm{VI}$ & .190 & ها - اغلب خودم را متهم مى كنم كه: (اكار اشتباهى انجام دادهاى!) \\
\hline$\cdot / v$ & $\cdot 19 \mathrm{~V}$ & 19 - اكر حواسم به خودم نباشد، ممكن است به آدمى تبديل شوم كه خيلى از آن مىترسم. \\
\hline$\cdot 199$ & $\cdot 199$ & IV \\
\hline$\cdot / v$ & $\cdot 199$ & 11- مى ترسم به آدمى تبديل شوم كه از آن نفرت دارم. \\
\hline$\cdot 199$ & .190 & 19 - اغلب احساس مى كنم كه واقعيتهاى درون خودم را با صداقت نشان نمىدهم. \\
\hline$\cdot 194$ & $\cdot 109$ & •r- بايد حواسم را حسابى جمع كنم تا كار خيلى بدى انجام ندهم. \\
\hline
\end{tabular}

محاسبه شد. جنانكه در اين جدول نيز مشاهده مى گردد

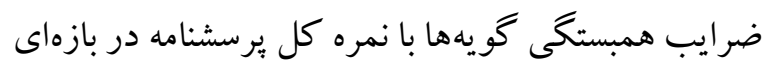

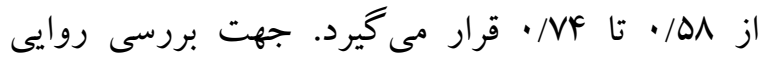
همخراى نسخه فارسى يرسشنامه ترس از خود از ضريب همبستكى نمره حاصل از اين برسشنامه با نمرات جهار

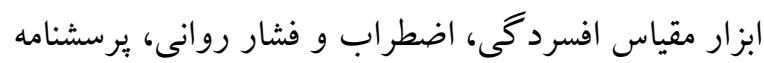
وسواس فكرى و عملى مادزلى، يرسشنامه باورهاى وسو اسى و برسشنامه دوسو گرايى به خود استفاده گرديد.
جنانكه در جدول r مشاهده مى گ

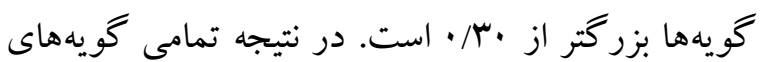
نسخه اصلى يرسشنامه ترس از خود در نسخه فارسى آن نيز حفظ شده است. بيشترين بار عاملى نيز متعلق به كويه شماره • ا (معادل NVV/•) و كمترين بارعاملى متعلق به

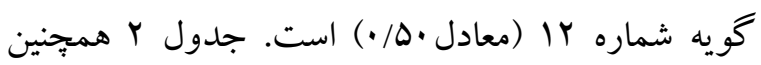
حاوى ضرايب همبستخى مربوط به نمره هر سؤال با نمره كل برسشنامه است كه به عنوان شاخص ديكرى از روايى مربى نسخه فارسى برسشنامه ترس از خود در اين يثوهش

\begin{tabular}{|c|c|}
\hline همبستغى با نسخه فارسى & ابزار \\
\hline$\cdot / 94$ & يرسشنامه DASS-21: خرده مقياس افردكى \\
\hline$\cdot / 94$ & يرسشنامه DASS-21: خرده مقياس اضطراب \\
\hline$\cdot / 94$ & ير سشنامه DASS-21: خرده مقياس فشار روانى \\
\hline$\cdot / 49$ & يرسنامه وسواس فكرى و عملى مادزلى (MOCI) \\
\hline$\cdot / \Delta V$ & ير سشنامه OBQ-44: خرده مقياس مسئوليت بذيرى \\
\hline$\cdot / 01$ & يرسنامه OBQ-44: كمال طلبى /نياز به اطمينان \\
\hline$\cdot / \Delta r$ & ير سشنامه OBQ-44: اهميت و كنترل افكار \\
\hline
\end{tabular}

مجله روانشناسى و روانيزشكى شناخت، سال هشتم، شماره 9، . . IF-Y4، 
روايى محتوايى برسشنامه ترس از خود در اين يُوهش، همانند يافته هاى طراحان برسشنامه در جامعه غير بالينى

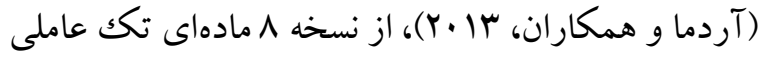

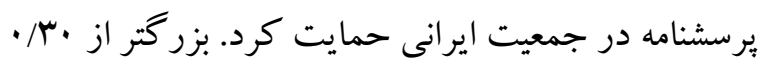
بودن بار عاملى تمامى گويهها نشان داد كه تمام گويههاى نسخه اصلى يرسشنامه در نسخه فارسى حفظشده است؛ كه نشان از سودمندى برسشنامه در كاربردهاى بالينى و مطالعات يثزوهشى در زمينه وسواس است. ضرايب

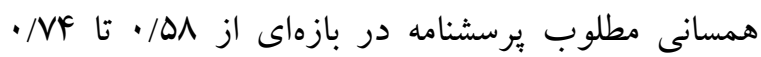
نشانگر همبستكى و انسجام گويهها در ارتباط با همديخر بود. همخوان با يافتهاى ئزوهشهاى بيشين از قبيل رووا،

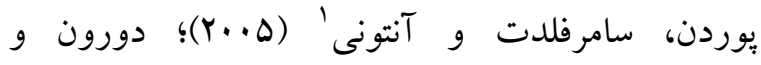

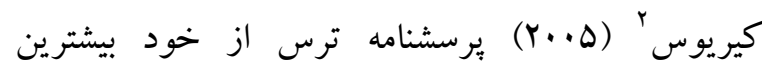
همبستكى معنادار (NI/•) با نزديككترين سازه به اين مفهوم (دوسو گرايى خود) داشت كه مؤيد روايى همخرا برسشنامه است (آكويلار، سوريانو، رونكرو، بارادا، آردما

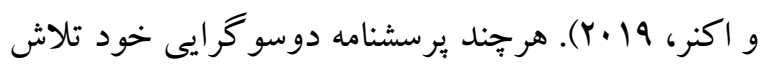
دارد يكك خودينداره دو گانه در مورد خود ترس يا بد بد بودن را اندازهگيرى كند و آيتمهاى در برسشنامه وجود دارد كه ترس از خود را اندازهگيرى مى كنند؛ ولى با اين

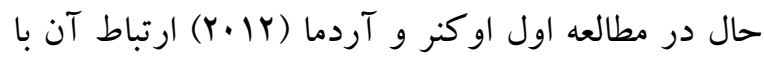
علائم وسواس تائيد نشده است؛ اما در ئزوهش حاضر

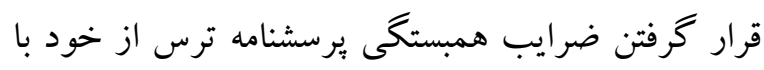
سه خرده مقياس يرسشنامه باورهاى وسواسى يعنى مسئوليت يذيرى و ارزيابى تهلديد و خطر، كمالطبى / نياز

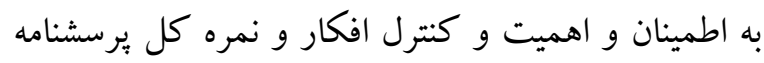

1- Rowa, Purdon, Summerfeldt \& Antony

2 - Doron \& Kyrios
جنانكه جدول ץ نشان مىدهد ضرايب همبستكى نسخه

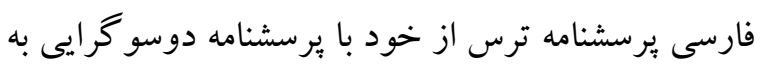

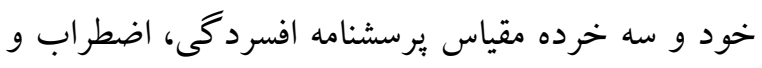

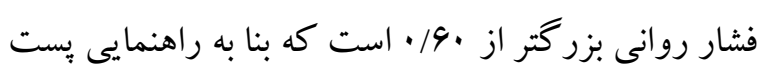
(Y.19) شاخصى عالى از روايى همخرا تلقى مىشود. ضرايب همبستكى برسشنامه ترس از خود با سه خرده مقياس :رسشنامه باورهاى وسواسى يعنى مسئوليت يذيرى و ارزيابى تهايد و خطر، كمالطلبى / نياز به اطمينان و اهميت و كنترل افكار و نمره كل يرسشنامه وسواس فكرى و عملى مادزلى نيز در بازه اس/· تا •و/ • قرار مى گيرند كه بنا به مرجع بالا، شاخص هايى مناسب از روايى همخرا به حساب مى آيند. جهت بررسى يايايى نسخه فارسى برسشنامه ترس از خود از سه روش محاسبه ضريب بازآزمايى، محاسبه ضريب آلفاى كرونباخ و محاسبه ضريب امگاى مككدونالد

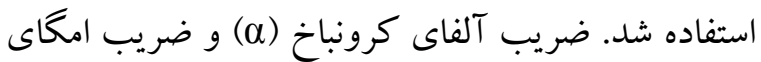

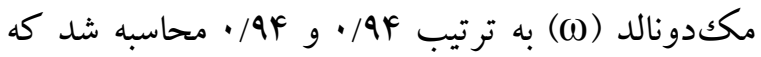
بنا به نظر تيبر (Y) تلقى مىشود. جهت بررسى ثبات زمانى نسخه فارسى

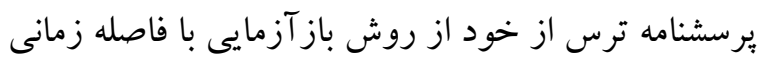

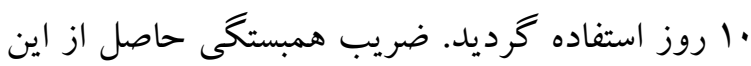
دو بار اجراى برسشنامه نيز معادل N9/، محاسبه شد كه بنا

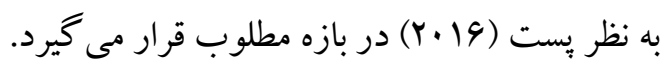

يزوهش حاضر با هدف بررسى ويز گیىهاى روانسنجى نسخه فارسى يرسشنامه ترس از خود در ارتباط با علائم وسواس در جامعه ايرانى انجام شد. نتايج علاوه بر تائيد 
شده و زمينه نفوذ افكار و وسواس در آنان ايجاد شود. تائيد ثبات زمانى يرسشنامه ترس از خود به روش باز آزمايى در دو نوبت به فاصله زمانى ·ل روز كويا اين مسئله بود كه سازه ترس از خود از ثبات برخوردار است.

\section{نتيجه كيرى}

ازآنجايى كه نتايج اين وئزوهش، بيانكر ارتباط مضامين شناختى خود ارجاعى مرتبط با ترس از خود با علائم وسواس بود، مىتوان نتيجه گرفت توجه به اين سازه در درمانهاى شناختى مى تواند بالقوه كارايى مداخلات را افزايش دهد. اين مطالعه يك بثزوهش مقطعى، مبتنى بر برسشنامه و در جامعه غير بالينى بود. طبيعتاً هركونه

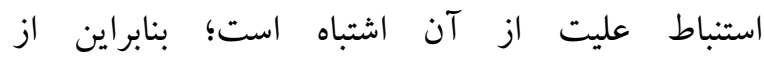
محدوديتهاى اصلى اين يزوهش، عدم مقايسه اين سازه در جمعيت بالينى وسواس و وارسى دقيق شناختهاى مرتبط با ترس از خود به كمكك ساير شيوههاى اندازهيرى بود؛ و از آنجايى كه بثزوهشها مشخص نكردهاند كه آيا ترس از خود نتيجه برخوردارى از علائم وسواس است يا اينكه ييش از شكل گيرى وسواس وجود داشته است؛ بنابراين بيشنهاد مىشود در بروهشهاى آتى، نقش ترس از خود در ابتلا به وسواس در طرحهاى طولى و در جمعيتهاى بالينى مورد بررسى قرار گيرد.

\section{سياسگز ارى}

از تمامى دانشجويان عزيز دانشگاه شيراز كه مشاركت در بثزوهش حاضر را خالصانه يذيرفتند به بِاس همكارى و همراهى دلسوزانه كمال تشكر و قدردانى را داريم. همجنين از سر كار خانم دكتر صادق زاده كه با در اختيار قرار دادن نسخه اصلى مقياس و تجربيات ارزشمندشان در اين حوزه ما را يارى رساندند كمال تشكر را داريم. مقاله
وسواس فكرى و عملى مادزلى در بازه اس/· تا .19• نشاندهنده روايى همخرا و ارتباط بيشتر سازه ترس از خود نسبت به دوسو گرايى در بيشينى وسواس است. ازآنجايى كه علائم برجسته شناختى وسواس، سيطره و ارزيابى افكار نافذ ناهمخوان با خود در زمينه ترس از آن جيزى كه فرد احتمال مىدهد ممكن است باشد يا به آن

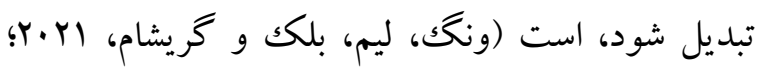

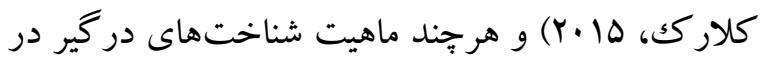
وسواس كستردهتر از محدوده اين مطالعه است؛ اما نتايج اين بزّوهش در راستاى بزوهش (او كنر، آردما و بليسير، ه · P. مشخص كرد كه فرايندهاى شناختى و ابعاد خود فراتر از باورهاى وسواسى وجود دارند كه مىتواند در وسواس نقش بالقوه بازى كنند؛ بنابراين همان طور كه آردما و همكاران (r/r) بيان مى كنند به نظر مىرسد يرسشنامه ترس از خود ساختارهايى از شناخت را اندازهـ

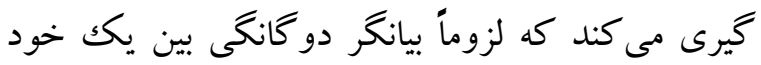

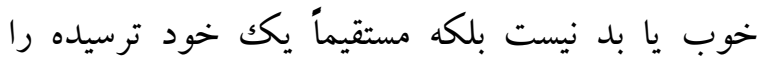
اندازه گيرى مى كند كه هيج يايه و اساسى در واقعيت ندارد. وجود ارتباط قوى بين شناختهاى درگير در وسواس از قبيل تهلديد، كمال گرايى و اهميت افكار با علائم وسواس نشان مىدهد كه فرد در گير شناخت هايى است كه نمى خواهد وجود داشته باشد و هميشه نغران خطرى است كه به دنبال آن ممكن است اتفاق بيفتد

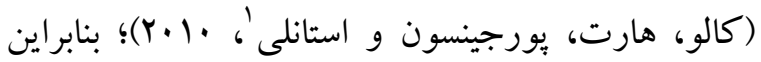
همان گونه كه در اين يزوهش ارتباط قوى ترس از خود با باورهاى وسواسى به دست آمد منطقى به نظر مىرسد

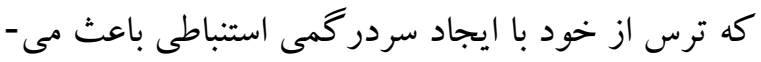
شود افراد به جاى مشاهده واقعيت افكار، غرق در افكار

1 - Calleo, Hart, Björgvinsson \& Stanley 
disorder. Behavioral Research Therapy, 45 (8): 1845-57.

Calleo JS, Hart J, Björgvinsson T, Stanley MA. (2010). Obsessions and worry beliefs in an inpatient OCD population. Joumal of Anxiety Disorder, 24,903-908.

Cervin S, Pemin E, Olsson E, Claesdotter-Knutsson M, Lindvall. (2020). Incompleteness, harm avoidance, and disgust: A comparison of youth with $\mathrm{OCD}$, anxiety disorders, and no psychiatric disorder. Joumal of Anxiety Disorders, 69, 10.

Clark DA. (2015). Innovation in obsessive-compulsive disorder. A commentary. Joumal of Behavior Therapy and Experimental Psychiatry, 49, 129-132.

Dadfarnia Sh, Mosavian E. (2020). The Psychometric Properties of Persian Version of SelfAmbivalence Measure about Obsessive Compulsive Disorder. Joumal of clinical psychology, 12(3):47. 35-46. (In Persian)

Doron G, Kyrios M. (2005). Obsessive-compulsive disorder. A review of possible specific internal representations within a broader cognitive theory. Clinical Psychology Review. 25, 415432.

Gagne JP, Van Kirk N, Hemandez-Vallant A, Potluri S, Krompinger JW, Cattie JE, Gamer LE, Crosby JM, Brennan BP, Elias JA. (2018). Validating an abbreviated version of the Obsessive Beliefs Questionnaire. Journal of clinical psychology. 74(10):1791-807.

Gruner P, Pittenger C. (2017). Cognitive inflexibility in obsessive-compulsive disorder. Neuroscience. 345, 243-255.

Guidano VF, Liotti G. (1983). Cognitive processes and emotional disorders: A structural approach to psychotherapy: Guilford Press.

Hezel DM, McNally RJ. (2016). A Theoretical review of cognitive biases and deficits in obsessivecompulsive disorder. Biological Psychology, 121, 221-232.

Hodgson RJ, Rachman S. (1997). Obsessionalcompulsive complaints. Behavioral Research Therapy.15 (5), 389-95.
PVDFq11 مستخرج از باياننامه كارشناسى ارشد به شماره دانشگاه سلمان فارسى كازرون مىباشد.

\section{References}

Aardema F, Moulding R, Melli G, Radomsky AS, Doron G, Audet JS, Purcell-Lalonde M. (2018). The Role of feared possible selves in obsessive-compulsive and related disorders: A comparative analysis of a core cognitive self-construct in clinical samples. Clinical Psychology Psychotherapy. 25(1), 19-29. Doi: 10.1002/cpp.2121.

Aardema F, Moulding R, Radomsky AS, Doron G, Allamby J, Souki E. (2013). Fear of self and obsessionality: Development and validation of the Fear of Self Questionnaire. Joumal of Obsessive-Compulsive and Related Disorders, 2: 306-315.

Aardema F, Wong SF, Audet JS, Melli G, Baraby LP. (2019). Reduced fear-of-self is associated with improvement in concems related to repugnant obsessions in obsessive-compulsive disorder. British Journal of Clinical Psychology, 58 (3): 327-341.doi: 10.1111/bjc.12214.

Aazami Y, Khanjani M, Sader MM. (2017). Confirmatory Factor Structure of Depression, Anxiety and Stress Scale in Students. Joumal of Mazandaran University of Medical Sciences, 27 (154), 94-106. (In Persian)

Aguilar SL, Soriano G, Roncero M, Barrada JR, Armada F, Ocner K. (2019). Validation of the Spanish version of the Fear of Self Questionnaire. Joumal of ObsessiveCompulsive and Related Disorders. 21, 69-74.

Ayre C, Scally AJ. (2013). Critical Values for Lawshe's Content Validity Ratio: Revisiting the Original Methods of Calculation. Measurement and Evaluation in Counseling and Development. 13,47(1): 79-86.

Bentler PM, Chou CH. (1987). Practical issues in structural modeling. Sociological Methods and Research. 16, 78-117.

Bhar SS, Kyrios M. (2007). An investigation of selfambivalence in obsessive-compulsive 
Hooper D, Coughlan J, Mullen M. (2008). Structural Equation Modelling: Guidelines for determining model fit. Electronic Joumal of Business Research Methods, 6(1): 53.

Kim S, Lee SW, Cha H, Kim E, Chang Y, Lee S. (2021). Reconciliation of Two Cognitive Models in Obsessive-Compulsive Disorder: An fMRI Study. Psychiatry Investigation, 18(6), 545-552.

Lovibond PF, Lovibond SH. (1995). The structure of negative emotional states: Comparison of the Depression Anxiety Stress Scales (DASS) with the Beck Depression and Anxiety Inventories. Behavioral Research Therapy. 1; 33(3), 335-43.

Nasiri M, Karsazi H. (2020). Predicting the obsessivecompulsive disorder and phobias based on components of disgust sensitivity. Joumal of Modern Psychological Researches, 15(59), 142-155. (In Persian)

O'Connor K, Aardema F, Pelissier MC. (2005). Beyond reasonable doubt: Reasoning processes in obsessive-compulsive and related disorders. New York: Wiley \& Sons.

O'Connor K, Aardema F. (2012). The clinician's OCD manual: Inference based therapy. Chi Chester, UK: Wiley.

Post MW. (2016). What to do With "Moderate" Reliability and Validity Coefficients? Archives of Physical Medicine and Rehabilitation, 97(7), 1051-1052.

Ribeiro JS, Pereira AT, Martins MJ, Nogueira V, Soares MJ, Amaral AP, Macedo A. (2017). Confirmatory factor analyses of the Portuguese version of the Maudsley obsessional-compulsive inventory.European Psychiatry, 41(S1), S80-S81.

Rowa K, Purdon C, Summerfeldt LJ, Antony MM. (2005). Why are some obsessions more upsetting than others? Behavioral Research Therapy, 43, 1453-1465.

Salkovskis PM, Kobori O. (2015). Reassuringly calm? Self-reported patterns of responses to reassurance seeking in obsessive compulsive disorder. Journal Behavioral Therapy Experimental Psychiatry. 49, 203-8.
Shahamat Dehsorkh F. (2017). Obsessive believes and Cognitive Inhibition deficit in in Obsessive Compulsive Patients. Journal of Cognitive Psychology. 5(2), 11-20. (In Persian)

Shams G, Esmaili Y, Karamghadiri N, Ebrahimhkani N, Yousefi Y, McKay D. (2013). Psychometric properties of the Persian language version of Obsessive Beliefs Questionnaire (OBQ-44) in Iranian general population. Acta Medica Iranica. 66-75. (In Persian)

Taber KS. (2018). The Use ofCronbach's Alpha When Developing and Reporting Research Instruments in Science Education. Research SocietyEducation. 48: 1273-1296.

Tisher R, Allen JS, Crouch W. (2014). The Self-Ambivalence Measure: A psychometric investigation. Australian Joumal of Psychology. 66(3), 197-206.

Wilson M. (2020). Fear of self in eating disorders. Joumal of Obsessive-Compulsive and Related Disorders, 27(187), 100562.

Wong FS, Lim V, Black MI, Grisham JR. (2021). The impact of modifying obsessive-compulsive beliefs about perfectionism. Joumal of Behavior Therapy and Experimental Psychiatry, 73.

World Health Organization (WHO). Process of translation and adaptation of instruments. (2006). Available online at: https://www.who.int/substance_abuse/researc $\mathrm{h}$ tools/translation/en/

Zanon C, Brenner RE, Baptista MN, Vogel DL, Rubin M, Al-Darmaki FR, Goncalves M, Heath PJ, Liao HY, Mackenzie CS, Topkaya N. (2020). Examining the dimensionality, reliability, and invariance of the Depression, Anxiety, and Stress Scale-21 (DASS-21) across eight countries. Assessment. 9, 1073. 